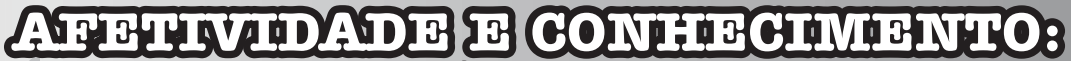 AAPROPRTAGATODA IFIYURADDA

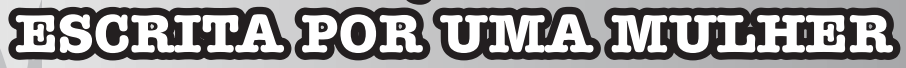

Raimundo Nonato de Oliveira FALABELO Campus Universitário de Cametá/UFPA falabelo@ufpa.br

Introdução

Buscamos palavras/que possam contar de nossos ofícios. Mas todas, embora/do fundo brotadas, resvalam, deslizam por sobre a camada/de tempo e distância. Thiago de Mello (2001)

O que significa a aprendizagem da leitura e escrita para uma mulher adulta, em uma classe de jovens e adultos, em um distante e empobrecido bairro periférico? Como ela se relaciona com a leitura e a escrita? Que sentidos dão-se a ver em sua luta para dominar essas ferramentas simbólicas? Como se dá o entrelaçamento afeto e cognição e sua mediação no processo de aprendizagem?

O presente trabalho procura analisar essas questões, por meio da narrativização de alguns episódios envolvendo uma aluna adulta. $\mathrm{O}$ estudo tem como referencial teórico a abordagem histórico-cultural desenvolvida por VYGOTSKY e a teoria da enunciação, de BAKHTHIN, que reconhecem que o homem é um sujeito simbólico e que o social, e o cultural-, entre as quais a linguagem - desempenham um papel fundamental na constituição da vida psíquica, constituída pela indissociável inter-relação entre vida afetiva e cognitiva.

Examino a questão da dimensão afetiva nas relações de ensino, procurando evidenciar como interpenetram-se e afetam-se mutuamente afetividade e cognição nos processos de aprendizagem 
de leitura e escrita. Busco, assim, estudar o afetivo em uma perspectiva inter-relacional, com a cognição, como constitutivos de uma mesma unidade, que é a vida psíquica humana. Ou seja, parto do pressuposto de que o afeto está presente e é constitutivo de toda e qualquer ação humana. Assim, procuro compreender como afetividade/emoções e cognição se inter-relacionam nas situações de ensino e aprendizagem, no contexto das dinâmicas interativas em sala de aula, em suas condições sociais e imediatas de produção.

O trabalho de campo foi realizado em duas classes de EJA, que funcionavam em um distante bairro periférico de uma cidade do interior de São Paulo, aqui denominada com o nome fictício de Primavera do Sol. A escolha dos episódios foi feita muito mais como, enquanto pesquisador, fui sendo afetado pelas singularidades dos sujeitos. Observei, então, entre esses episódios uma diversidade de gênero/geração que procurei manter. Foram esses episódios organizados em forma de narrativas.

Considero importante ressaltar que nesses exercícios, que estou chamando de narrativas, vou destacando e analisando os indícios dos aspectos afetivos, que vão sendo tecidos na sala de aula, mediadas pelo conhecimento em circulação e em elaboração.

Os fenômenos afetivos, mesmo em sua natureza subjetiva, segundo Pino, não são independentes da ação do meio social, pois através do processo educativo o sujeito adquire as funções psicológicas e os padrões culturais de seu grupo, de forma que "o homem é educado não apenas para pensar e agir dentro desse padrão cultural, mas também para sentir e reagir de acordo com eles". Para Pino, a compreensão dos aspectos afetivos passa, necessariamente, "por um trabalho de interpretação" (p. 128), e que este é possível porque "os integrantes de um mesmo grupo cultural têm referenciais comuns para interpretar as experiências afetivas dos outros membros 
do grupo, o que não impede, porém, que tais experiências sejam pessoais e diferenciadas" (mimeo, p.128). Deste modo, os fenômenos afetivos são exprimíveis ao outro e ao próprio indivíduo, e igualmente elaborados e compreensíveis "por meio de signos, nas relações intersubjetivas" (FONTANA, 2000b, p. 106). Assim, a aproximação aos indícios e às evidências dos aspectos afetivos - que se dão a ver na dinâmica das relações de ensino e aprendizagem - realiza-se por meio dos significados que os sujeitos apropriaram-se no processo educativo e que são compartilhados social e culturalmente (TASSONI, 2000). Há, assim, significados estabilizados e consensualmente aceitos que permitem aos sujeitos interpretar determinados gestos, expressões faciais, variações na tonalidade das enunciações, etc., como manifestações afetivas de alegria, medo, ira, tristeza, prazer, acolhimento, conflito etc..

Nas observações, procurei os indícios das manifestações afetivas, em suas condições imediatas e concretas de produção, as quais se objetivam em um material determinado: a) no contato físico-corporal: gestos de afagos, abraços etc.; b) nas expressões não-verbais: expressões corporais, tônico-posturais, olhares, gestos, expressões faciais; c) na tonalidade das enunciações orais, isto é, na palavra: falas, dizeres, etc.; d) nas relações aluno-conhecimento: a forma como eram afetados pelos objetos simbólicos e os sentidos que enunciavam através de formas sígnicas verbais ou não: de prazer, alegria, satisfação, indiferença, negação, cansaço, dor, etc.; e) nas atitudes da professora em relação ao aluno: compreensão, paciência, irritação, reciprocidade, etc; na organização das atividades pedagógicas.

Precisando mais: as manifestações afetivas cristalizar-se-iam, aos olhos do observador, em suas formas de afetos/emoções: alegria, tristeza, afagos etc.. Assim, considero pertinente esclarecer que, ao longo do trabalho analítico, vou dando evidência aos afetos/emoções 
em ocorrência no próprio movimento narrativo.

Ainda, de acordo com os referenciais teórico-metodológicos assumidos, considero que organizar os dados em forma de narrativas que captem os eventos, as singularidades, as manifestações efêmeras, os gestos inusitados, é olhar para a sala de aula como constituída por sujeitos que, mesmo sob controles e estabilizações que a organização coletiva e as relações hierarquizadas de poder impõem, vão tecendo os fios de sua singularidade, produzindo sentidos, afetando-se mutuamente. Sujeitos que se dão a ver como desejo, necessidade, afetos e emoções, silêncios e possibilidades.

Nas narrativas, assim, vou buscando dar visibilidade aos indícios das manifestações afetivas - afetos e emoções - que ocorrem nas relações de ensino, procurando, fugir à leitura um tanto mecânica, causa - efeito, como habitualmente são enfocadas as relações professor-aluno-conhecimento. A narrativa nos possibilita construir ou reconstruir essas relações em seus múltiplos significados e sentidos, na imediaticidade de sua produção, pois, como observa Fontana (2000b):

Para nos acercarmos das relações interpessoais de indivíduos que vão se constituindo em condições sociais específicas e compreendê-las, mostram-se insuficientes as observações e análises objetivas que excluem as situações pontuais, efêmeras e contraditórias de dor e alegria, de serenidade e enfrentamento, de assentimento e de desobediência, ou os sentimentos de emoção, de angústia, de raiva, que são experimentados pelos sujeitos envolvidos em nossas indagações. Ao excluí-los, essas análises perdem de vista tanto "as pessoas", cujos comportamentos se deseja entender, quanto a dinâmica em que esses comportamentos nelas se constituíram e continuam se constituindo (2000b, p. 106).

Tecer episódios com fragmentos verbais e com a descrição das manifestações expressivas não-verbais, captados no lusco-fusco dos eventos em seu efêmero movimento, é uma forma de compreendermos as relações de ensino nas quais os momentos felizes não sejam totalmente anulados pelos momentos duros e tediosos da 
aprendizagem. Alegrias pontuais que se dissipam sob o rolo esmagador do evento em processo. Solidão, tristeza no aprendizado. $\mathrm{O}$ ato único e singular de constituir-se na relação com o outro não pode fazer-se apartado de um certo tom de agrado, de felicidade. Por trás do sacrifício, o sonho do obstáculo transposto, acontecimento que se abre ao fluir e fruir da emoção: a alegria, o prazer, com o sujeito que se compreendendo e fazendo-se na interação com o outro, nas relações de conhecimento. No movimento em sala de aula, seus participantes - alunos, alunas, professoras - vão se dando a ver nos acontecimentos. São esses acontecimentos que elegi para compor minhas narrativas.

Acho importante destacar, ainda, como estou utilizando o termo narrativa: para tratar da minha experiência como pesquisador na sala de aula; para tratar de minha experiência de aproximação das tramas afetivas que se tecem entre os sujeitos.

Ao fazer a opção pelo registro dos dados empíricos em seus aspectos singulares, fragmentários, para compor as narrativas, não posso deixar de mencionar aqui, mesmo que brevemente, as contribuições dos estudos de Ginzburg sobre o paradigma indiciário ou semiótico. Ginzburg (1989) faz um levantamento minucioso sobre as raízes desse paradigma, a qual se encontraria nas atividades de nossos longínquos ancestrais caçadores. Diz ele que, por milênios, foi o homem um caçador que aprendeu a farejar, registrar e interpretar a partir das infinitas e diversas pistas deixadas por presas invisíveis.

No final do século XIX, as ciências humanas começam a experimentar um paradigma indiciário, baseado na semiótica, o qual privilegia o estudo interpretativo de aspectos individuais, singulares, fragmentários, isto é, de pormenores negligenciáveis, evidências a princípio irrelevantes, como forma de se conhecer um determinado fenômeno. Esse paradigma, no entanto, diz Ginzburg, tem suas 
origens nos distantes saberes dos caçadores - patrimônio cognoscitivo enriquecido e transmitido ao longo das gerações. Assim, "por trás desse paradigma indiciário ou divinatório, entrevê-se o gesto talvez mais antigo da história intelectual do gênero humano: o do caçador agachado na lama, que escruta as pistas da presa" (1989, p. 154).

Ginzburg sugere que provavelmente "a idéia de narrativa tenha nascido, pela primeira vez, numa sociedade de caçadores a partir da experiência da decifração das pistas" (p.152), o que colocava a necessidade de dispor os dados - as pistas, os indícios - em uma ordem seqüencial. A narrativa, assim, apresentava-se ao observador como uma maneira de organizar e interpretar os dados e dar-lhes unidade e coerência.

Deve-se ressaltar, ainda, que apesar do paradigma indiciário privilegiar o singular, o fragmento, a idéia de totalidade não lhe é ausente. Pelo contrário, o conhecimento do fenômeno dá-se pela inter-relação com os seus aspectos singulares. Como diz Ginzburg: "A existência de uma profunda conexão que explica os fenômenos superficiais é reforçada no próprio momento em que se afirma que um conhecimento direto de tal conexão não é possível. Se a realidade é opaca, existem zonas privilegiadas - sinais, indícios - que permitem decifrá-la"(p. 177).

\section{A narrativa}

Women will starve in silence until new stories are created which confer on them the power of naming themselves.

HEILBRUN, C. G (1988)

A professora mantém uma descontraída interlocução com a turma, sobre assuntos triviais, enquanto vai copiando o exercício de matemática no quadro. O balbuciar de uma aluna, atrás de mim, desperta minha atenção. Apuro os ouvidos mas não consigo decifrar o 
que ela pronuncia.

Depois de uns longos minutos, silêncio. Repentinamente, ouso olhar para trás. Sentindo-se observada, a aluna levanta a vista. "Eu não consigo gravar essas letras" - fala-me, meio constrangida, semblante de decepção, com uma voz sumida. Olho para o seu caderno e vejo as vogais copiadas. Estava soletrando-as, todo esse tempo, compreendo finalmente. Parou porque se atrapalhou e não sabe continuar.

É uma jovem senhora, em torno dos 42 anos. Volto-me às minhas anotações. D. Maria de Nazaré recomeça seu murmúrio ininterrupto, com a ajuda da professora que, vendo-a em silêncio, naquela situação de desconforto, veio em seu socorro. - "Maria de Nazaré, deixa eu ver sua liçãozinha, bem?" E minutos depois: " - Tem que treinar mais, depois vou ver sua leitura".

- "Essa letra eu faço sozinha sem errar" - diz a aluna, justificandose, com sua fugidia voz, como que pedindo desculpas à professora. "Mas tenha paciência que você consegue" - incentiva-a. Lança-me um olhar como que pedindo confirmação às suas palavras. Volta-se para o quadro. - "Tenho dificuldade de gravar [as letras]" - murmurame D. Maria de Nazaré, alguns minutos depois, enquanto observo seu caderno.

D. Maria experimenta, em sua versão mais cáustica e dramática, a herança de uma concepção de alfabetização ${ }^{1}$ historicamente consolidada, que pressupõe a aprendizagem da língua em sua forma fragmentária e divorciada do contexto histórico-cultural dos sujeitos. Para essa concepção, o pressuposto fundamental é o treino mecânico da forma do alfabeto e não a interação significativa com o conteúdo da língua. A aprendizagem resume-se a uma técnica de oralização dos

1 - Método sintético: O caminho sintético tem seu ponto de partida no estudo dos elementos da língua - letra, fonema, sílaba. E considera o processos de leitura como um esquema somatório: pela soma dos elementos mínimos - o fonema ou a sílaba -, o 
elementos da escrita.

Após a entrada do intervalo, D. Maria de Nazaré pede para sair. "Gente, ela tem que sair, está com dor de cabeça, toma remédio controlado... Ela tá vivendo uma grande angústia... Acha que o patrão dela não paga ela direito... Outro dia pediu para eu fazer umas contas para ela... Agora, recebeu seu pagamento e foi fazer dois pagamentos e acha que foi enganada, deu dinheiro demais e não recebeu o troco certo... Ela está com vontade de aprender tudo de uma vez, mas já falei para ela que não pode... Quem fazia os pagamentos para ela, era o companheiro dela, mas eles estão deixados, ela se encontra nessa dificuldade" - fala a professora à turma, que, por suas atitudes, muitas conversas paralelas entre adolescentes, principalmente, parece pouco interessada nos problemas anunciados. Parece-me, no entanto, que a professora dirigia-se mais a mim, seu olhar centrava-se em minha direção.

Sem a possibilidade do prazer da aprendizagem, o drama da aluna se acentua: uma analfabeta, que precisa urgentemente dos recursos da escrita e da aritmética para constituir-se cidadã: conhecer e reivindicar seus direitos elementares, como fazer um pagamento e saber conferir o troco. Compreendo agora seu esforço: passou, no primeiro horário da aula, das $19 \mathrm{~h}$. às $20 \mathrm{~h} 40 \mathrm{~m}$, cem minutos, repetindo, ininterruptamente, com umas duas ajudas da professora, as vogais. Cem minutos!!, sentada na carteira, oralizando, a mesma coisa: a, e, i , o, u - escritas toscamente em seu caderno.

Nada mais de material. Dois processos diametralmente opostos: de um lado, a ânsia e a urgência com que Maria enfrenta a necessidade de seu aprendizado da escrita e, de outro, uma aprendizagem empobrecida.

Em uma perspectiva de aprendizagem histórico-cultural, segundo Vigotski, o homem humaniza-se mediado pela cultura, interagindo com os signos culturais. Como pensar a aprendizagem e o processo de 
singularização de D. Maria de Nazaré, a partir dos objetos que a escola oferece para a mediação no processo de ensino? Vigotski (200b, 1997) sustenta a tese da importância da aprendizagem para o desenvolvimento das funções psicológicas superiores, destacando o papel da escola enquanto locus desse desenvolvimento. Mas Vigotski (1997) defende uma escola de qualidade, com experiências significativas que promovam aquelas capacidades ainda não dominadas pelo indivíduo, ou seja, a escola, não deve limitar-se a ensinar o que o aluno já sabe, mas atuar, principalmente, naqueles aspectos em emergência. Aí são fundamentais, portanto, as experiências culturais mediadas pelo outro, que o indivíduo tem acesso.

Outro dia de observação. Os alunos continuam chegando, aos poucos, com o mesmo caminhar vagaroso de sempre. A professora conversa assuntos corriqueiros. - "Você sabe que dia é amanhã, Celso, é dia do professor, só que vamos ter aula ... Hoje vou soltar todos um pouco mais cedo, viu seu Nestorino?, e vou ficar treinando um pouco mais com seu Nestorino e Maria de Nazaré" - anuncia a professora sua intenção que, na verdade, ficou apenas na intenção.

D. Maria de Nazaré chega puxando uma criança, de uns seis ou sete anos, pela mão. Com seu jeito tímido, sua voz quase inaudível, aproxima-se da professora: - Fiz todo o dever, professora. - Depois vou ver - promete, secamente, com indiferença, lançando-lhe um furtivo olhar, voltando-se aos assuntos triviais.

Algum tempo depois, a professora deixa o quadro e vai até D. Maria e a ajuda em sua tarefa, que se resume a desenhar algumas letras. O lápis vai deslizando com dificuldades por sobre o papel. Sua fisionomia demonstra que a atividade exige-lhe um esforço tremendo. Aproveito a proximidade da professora para perguntar-lhe sobre a aluna. 
- "Ela chegou, coitadinha, com uma sede de aprender! Agora ela tá fazendo o alfabeto. Ela tá com dificuldade na letra 'e'. Ela está fazendo as letrinhas... Ela tá há uns três dias na classe. Já decorou o $\underline{\mathrm{a}}, \underline{\mathrm{i}}, \underline{\mathrm{o}}, \underline{\mathrm{u}}$,

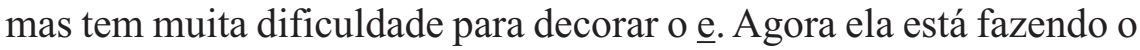
alfabeto. Já ensinei pra ela que as vogais estão no meio das outras. Ela precisa treinar bastante. Tem aluno que leva muito tempo para decorar as vogais... mas não pode forçar, tem que ir devagar... tem que ir por parte. Tenho uma pena deles, coitadinhos, mas é o que posso fazer." diz-me ela, em sua expressão de piedade. "-Eu me dou conta de que não sei nada... vejo no meu computador lá em casa e penso nesses coitadinhos, aqui, e vejo como eles sabem tão pouco... Aprendi com a minha diretora: ela dizia que é preciso ensinar a fazer as continhas, ensinar a ler um pouco... A gente acaba fazendo tudo, pois tenho que ajudá-los até a preencher formulários da Caixa Econômica etc... Antes, eu planejava 3, 4 aulas seguidas, mas descobri que não dá para ficar enchendo, enchendo eles assim... Tem que ir devagar... Eles são muito lentos... Tem que ver a prontidão deles..."

Nessas condições, o processo de aprender a ler e escrever, ao submeter o sujeito da aprendizagem a uma relação abstrata e mecânica com o conhecimento, produz determinadas situações afetivo-emocionais indiciadas em gestos, expressões, atitudes, signos verbais e não verbais que enunciam as formas de relação que o sujeito está mantendo com o conhecimento: de aceitação, indiferença, de negação, de prazer, de sofrimento. Naquilo que é específico das relações intersubjetivas em sala de aula, é no movimento da relação com o conhecimento, neste caso, leitura e escrita, que vão se produzindo as manifestações afetivo-emocionais do sujeito.

Nesse processo interativo, d. Maria de Nazaré vive um conjunto de manifestações afetivas que se indiciam em seus gestos e enunciações, como: ansiedade gerada pela necessidade de aprender; sofrimento e dor que parecem não encontrar recompensa no seu esforço; angústia, 
desconforto, decepção, sentimento de culpa, vergonha e constrangimento ante o não saber fazer uma letrinha, por exemplo.

Por outro lado, nessa prática pedagógica vão-se desvelando os indícios não apenas da constituição da subjetividade de uma professora, mas como essa subjetividade se constitui historicamente, inserida no movimento da história e da cultura. "- Aprendi como minha diretora..." - diz a professora. Na relação com o outro, a professora forja e consolida em sua prática singular uma concepção de leitura e escrita que é social, histórica. "A 'palavra do outro'”, diz Bakhtin (2000), transforma-se, dialogicamente, para tornar-se 'palavra pessoal-alheia' com a ajuda de outras 'palavras do outro', e depois, palavra pessoal..." (p. 405). Pela prática pedagógica, dão-se a ver os elementos constitutivos das metodologias de alfabetização, dão-se a ver no movimento singular o movimento das relações sociais. A análise centra-se, assim, não numa professora como uma individualidade ideal apartada, isolada do movimento das relações sociais, mas na prática enquanto agregado daquelas relações, enquanto cristalização de determinadas concepções teórico-práticas.

D. Maria de Nazaré continua a desenhar as letras. Vejo seu esforço, sua expressão fisionômica demonstra o quanto está concentrada na atividade. Está como que em um mundo a parte. Nada a perturba. Não a vejo, sequer, desviar o olhar de seu caderno e de seu lápis. Nem os risos de alguns alunos, nem suas brincadeiras espalhafatosas, nem a fala alta da professora dando orientação para algum aluno, nada parece abalar sua concentração. O lápis que copia é o mesmo que apaga num movimento sincrônico e ritmado, ininterrupto e infindável. Em algum raro momento, vejo-a descontrair o corpo na cadeira, espichar-se e voltar ao treino.

- "A gente não pode forçar, tem que ir bem devagar" - diz a professora, dirigindo-se a mim, no burburinho e na agitação que 
marcam a saída para o lanche. - "Se eles saírem sabendo fazer as continhas e lendo um pouco, já me dou por satisfeita!" - suspira, como que reforçando os pressupostos de seu método: alfabetização aos pedaços e um pouco de conhecimento para os alunos. Sem ambição, a professora apropria-se da palavra do outro, da diretora, e a toma como sua, para delimitar os horizontes dos objetivos de sua prática.

Entrada do lanche. D. Maria de Nazaré continua em sua interminável tarefa; concentrada, ar grave, expressão fechada, desenhando suas letrinhas. O movimento do lápis é lento. Cansaço e tensão vincam-lhe a face compungida, angustiada. Mas parece-me, ela continua firme no seu propósito. Seu corpo quase curvado, quase imóvel, sobre a carteira, mas sua fisionomia denuncia esse aparente ser imperturbável: agonia, é o que leio em sua face, músculos contraindo-se.

"- Vamos ver a D. Maria de Nazaré... Vamos dar uma lidinha aqui, bem?!". E ela vai balbuciando as letrinhas, inaudíveis para mim; ouço apenas a correção da professora aqui e ali, pronunciando-as.

“- Isso!!, feche o caderno e vamos treinar!!!. Treine bem!! aquela letrinha que você tem dificuldade" - diz a professora à aluna, que se arruma para sair, recomendando esse treino para casa. Ela levanta-se, caderno na mão, um leve e tímido sorriso nos lábios. Finalmente, dissipam-se em seu semblante aquele ar de mortificação. Vejo-a sumir no corredor, o caminhar tranqüilo, puxando a criança pelas mãos.

D. Nazaré vem sendo submetida a um procedimento de aprendizagem rudimentar e desumano; desumano porque limita o acesso ao conhecimento; desumano pelo quanto cerceia e impossibilita o acesso à escrita, à leitura significativa; desumano porque a impede de agir, explorar e interagir com a escrita; 
impossibilita-a de uma relação prazerosa com a escrita, enquanto aceitação. Os signos não-verbais que enuncia indiciam que a relação afetiva que ela estabelece com a escrita é de negação, de desprazer, angústia e sofrimento.

A aluna busca a escola em situação de quase desespero. Precisa urgentemente aprender para transitar por um mundo que lhe é hostil: é enganada pelo patrão, é lesada nos pagamentos que faz. Move-se numa atmosfera de solidão. Sua fisionomia expressa a angústia de alguém que mobiliza suas energias e seu pensamento, para resolver uma atividade, que lhe escapa pelas teias da memória. As letrinhas escorrem e perdem-se num esquecer constante e ininterrupto. Vigotski (2002a) nos chama a atenção para o fato de que o pensamento é gerado pelas nossas motivações, por nossos desejos e necessidades, nossos interesses e emoções. São essas emoções, geradas pela necessidade, que as movem.

No encontro e desencontro com as indomáveis letrinhas, abre-se o caminho para a afirmação de sua singularidade. Deve ser isso que faz com que ela resista, sentada em sua carteira: os únicos movimentos ritmados que observo são o de apagar e o de escrever. Um eterno recomeçar. A cabeça sempre baixa, de vez em quando um espreguiçar-se na carteira: tudo parece cansativo para ela, que já vem de um longa jornada de trabalho. Seu desejo de aprender a afeta tanto que, mesmo esfalfando-se na lide doméstica, ainda encontra tempo para fazer o dever de casa. "-Fiz o dever, professora" - em sua timidez, presta conta.

A cidadania - ou a imagem que se faz desta - para ela surge como algo a ser imediatamente conquistado; uma coisa de vida ou morte. "Se eu não aprender a ler em dois meses, eu não venho mais... Mas já aprendi mais coisinhas... Mas se eu aprender a ler, ah..." - suspira ela a uma colega, desejosa de viver uma emoção que lhe parece 
intangível. "- Tenho dificuldades nas letrinhas... a letra "e"....". E mostra-nos o caderno.

Ela deseja e necessita apropriar-se da leitura e escrita. Em suas emoções de angústia e nervosismo, dor de cabeça de tanto repetir a -e - $\mathrm{i}-\mathrm{O}-\mathrm{u}$, num interminável zun-zun-zun.... busca forças para conquistar-se: ser dona de si mesma, mas os resultados que colhe nessa alfabetização sem sentido parecem afastá-la para mais distante de seus objetivos. E, assim, a força emocional que a impulsiona para a conquista de seus propósitos, de superar suas dificuldades, parece que vai se transformando em obstáculo.

" - Sabe que outro dia eu fiquei a madrugada toda na delegacia porque eles não quiseram carimbar meu dedo... Nossa, sofri tanto... Disseram que eu e meu filho só iam sair de lá [delegacia] se eu assinasse... Meu filho pegou na minha mão e fui fazendo as letras, em três folhas de papel". Seu filho, menor de idade, fora detido por algum motivo que ela não esclareceu.

D. Maria de Nazaré busca uma cidadania que a escola, da forma como está organizada e funcionando, retarda e, de fato, nega... Não há como não questionar essa ordem: as condições reais, dramáticas e pobres, em que é dada a educação dos excluídos, dos trabalhadores, das mulheres pobres que vivem nas periferias das grandes cidades: porque já excluídas também do centro de todas as conquistas da ciência e do desenvolvimento histórico-cultural da humanidade. E é, justamente "por isso que temos de viver e experenciar a opressão dos corpos oprimidos - por em-patia, sim-patia e com-paixão - em vez de nos limitarmos à descrição ou à explicação da opressão como fato (educacional)"(ALMEIDA, 2001, p. 121).

Mais um dia de observação. O Ambiente da sala encontra-se agitado, com arrastar de carteiras, alguns alunos falam alto, discutem, arengam. Enquanto isso, como sempre, D. Maria de Nazaré continua, 
resignadamente, quieta em sua carteira, lendo parte do alfabeto, é o que percebo pelo movimento de seus lábios. Sentou-se ela um pouco distante de mim, hoje. Tem uma garotinha do seu lado, aproximadamente uns treze anos, que parece ajudá-la na tarefa. Como sempre, está a apagar e a escrever. A professora deixa o quadro e senta-se junto a ela. Acocorada, conversa e procura incentivá-la, fazlhe afagos no ombro, passa a mão suavemente por sobre seus cabelos. D. Maria de Nazaré, concentrada em sua atividade continua apresentando sinais de inconformismo, imagino, à lentidão de sua aprendizagem.

“- Tudo bem, vá devagarinho, depois a gente volta para aquela letrinha que você não acertou, tá bom? Não quero que você fique nervosa" - a professora conversa, demonstra sentimentos de preocupação com o estado emocional da aluna, tomada pelas emoções de tensão, ansiedade diante das dificuldades que enfrenta.

Algum tempo depois, a professora volta novamente a sentar-se ao lado dela e tenta acalmá-la: “- Não fique nervosa, Maria. Vamos fazer a letra cursiva e depois a letra palito" (letra de forma) - ressoa sua voz cheia de afetos: suave, mansa e consternada; uma das mãos afaga o ombro da aluna, em significativa atitude afetiva; olhar, emocionalmente complacente.

“- Acho que não vou aprender a ler, professora" - queixa-se a aluna. “-Como não, Maria? Você já está lendo, você já está lendo as letrinhas!!’. Mas, a expressão fisionômica de Maria é de indiferença, um semblante a anunciar emoções de tristeza, nervosismo e angústia com os resultados de sua aprendizagem. Parece que não acredita em si mesma e nem no que a professora lhe fala - parece desencantada, pressentindo o sentimento de derrota e de fracasso a rondar-lhe bem próximo.

“-É que eu fico muito nervosa...” - confessa ela, a uma colega, 
com um fio de voz. "...Mas já aprendi umas coisinhas" - tenta sorrir e alegrar-se, em seu jeito tímido, com o pequeno progresso. "- Já sabe escrever o nome?" - pergunto-lhe. "-Não, mas já sei fazer as letrinhas do meu nome" - responde-me ela, apontando para o caderno onde escreveu as letras.

D. Maria, parece-me, é a que mais demanda a atenção da professora, que está profundamente afetada por sua situação: a todo momento está junto a ela e sempre acalmando-a, pedindo-lhe para não ficar nervosa, para não desistir. A professora manifesta sentimentos de preocupação, medo em relação a uma possível desistência da aluna.

Essas interlocuções, no entanto, não diminuem o sofrimento; não eliminam a tensão emocional vivida pela aluna em sua relação com a leitura e escrita. Não são assim, apenas essas formas de demonstração afetiva, palavras de preocupação, de incentivo e afagos, que irão reverter a situação emocional de angústia, impaciência, frustração, nervosismo e decepção que vive a aluna em sua relação com o conhecimento. Ao mesmo tempo em que a professora investe nesse tipo de recurso afetivo, contrariamente, a própria prática pedagógica a nega, à medida em que esta provoca mais tensão, o que torna inócuas aquelas demonstrações afetivas.

Por uma certa lógica de pensar a questão afetiva, então, esse tipo de ação afetiva levaria a que D. Maria de Nazaré assumisse uma relação de aceitação, de progresso na sua aprendizagem. Mas não é o que acontece. Ela sofre porque quer aprender e se vê não aprendendo: manifesta seu estado afetivo-emocional nas entonações (não pela sonoridade de sua voz), através dos seus gestos, de suas expressões faciais, de suas atitudes, que são signos que indiciam a sua condição afetivo-emocional e significam a maneira como se relaciona com o conhecimento. Para Bakhtin, o material semiótico do psiquismo pode 
ser constituído por todo gesto ou processo do organismo, tais como a respiração, a circulação sangüínea, movimentos do corpo, a articulação, o discurso interior, a mímica, a reação aos estímulos exteriores, pois tudo o que ocorre no organismo pode se constituir em material para a expressão da atividade psíquica, tudo pode adquirir um valor semiótico (BAKHTIN, 1997).

Ouve-se apenas a voz da professora e raramente a de Maria, mas esta "fala" e essa sua voz vem por meio dos signos não-verbais: seu corpo mortificado, dá a ver a relação afetiva que mantém com a escrita. Ainda, a professora lê e compreende essa linguagem e com ela trava interação, pois recorre à sonoridade de sua voz para dar a ver o quanto a situação da aluna a afeta. Maria, por sua vez, usa a expressividade de sua corporeidade, carregada de signos, para indiciar sua emotiva insatisfação com a relação pedagógica. Essas enunciações desestabilizam a professora, que também se angustia, se preocupa, sofre. Nesta, também indiciam-se aquelas emoções vividas pela aluna: medo, ansiedade, angústia, sentimento de fracasso, desencanto etc.. Ou seja, nas relações intersubjetivas, todos afetamse e são afetados. Afeto é relação, isto é, inter-relação.

Maria, por meio de sua linguagem expressiva, de fato, nega o próprio método de aprendizagem que a escola lhe disponibiliza. É a prática que produz angústia, sofrimento, impaciência à medida em que ela vai compreendendo que seu esforço não produz resultados; é a prática que exclui Maria da possibilidade de apropriar-se do conhecimento, apesar dos investimentos da professora em afetos de afagos. Assim, esse tipo de manifestação afetiva torna-se sem efeito à medida em que a professora não disponibiliza outras saídas à aluna, não lhe mostra outros caminhos, senão o treino contínuo e ininterrupto.

A professora é competente em seu método. Na relação interpessoal é atenciosa, acolhedora, preocupada com a aluna, incentiva e auxilia a 
todo momento. Na relação com o conhecimento, esforça-se para que a aluna aproprie-se desse conhecimento em sua forma parcelar, fragmentária: incentiva o treinamento, a cópia, a oralização exaustivamente. Ainda, passa treino para casa. "- Você está com dificuldade naquela letrinha ${ }^{2}$, você ainda tem dificuldade de reconhecer o "e"... Mas, olhe, não precisa ficar nervosa... vá devagarinho...". "-Aquela outra que eu tenho dificuldade, fiquei em casa martelando" - justifica-se Maria, com sua voz emocionalmente frágil.

A professora exerce, com domínio, a vigilância epistemológica de sua pedagogia, que é dada pela sua preocupação excessiva em não perder o controle da situação de aprendizagem e nem deixar que a própria aluna se perca na impaciência e na pressa: sempre em alerta, sinaliza o percurso e suas implicações: é preciso paciência; a pressa não é bem-vinda, a aprendizagem é lenta, gradual, demorada. A angústia está implícita; os afagos, os incentivos visam atenuá-la. E, sobretudo, é preciso "treinar", "treinar" à exaustão e só então prosseguir...

“-Deixa eu adiantar o alfabeto da...[D. Maria de Nazaré] ... Só que nessas letras, você já fez as vogais...". A professora passa algumas (quatro, cinco) letras do alfabeto em linha vertical que D. Maria de Nazaré deverá repeti-las até à margem direita do caderno.

Certo dia, à saída para o lanche: “- D. Maria de Nazaré não veio

2 - Há muito tempo que se denuncia a infantilização da EJA, não apenas no plano da linguagem, mas, principalmente, na abordagem pedagógica e dos materiais didáticos utilizados. Presumo que parte dessa distorção deve ser creditada ao fato de que os professores alfabetizadores da EJA têm sua história construída na alfabetização de crianças no ensino regular. Outra parte, que não deixa de ser considerável, atribuo à falta de uma clara concepção político-pedagógica para a EJA, que no fundo, parece ser uma "terra de ninguém", subsistindo como uma estrutura pária dentro das estruturas das secretarias de educação, sejam estaduais ou municipais. Claro, que nesse quadro, haveria alguma pontual exceção à essa regra. 
hoje à aula?"- pergunto à professora Zilma, em frente à porta de sua sala. "- Não, não veio". Iniciamos uma conversa sobre a aluna. Ela, então, repete-me, mais uma vez, a dificuldade da aluna para aprender a letra " $e$ ": "- Ela tem umas dores de cabeça terríveis... Hoje ela não veio... Você sabe que ela tem a maior dificuldade para aprender a letra " $e$ ", dificuldade, dificuldade, dificuldade..."

A professora, ao repetir essas palavras, aperta a palma da mão direita na testa, inclina um pouco a cabeça para o lado e para baixo, enquanto sua face expressa uma mistura de sentimentos como: pesar, preocupação e cansaço; um sentimento de pena dado o esforço que Maria de Nazaré faz para aprender e não consegue. "- Ela vai, vai, lendo..., mas quando chega na letra " $e$ ", pronto, empaca... Não tem como fazer ela decorar a letra "e" continua explicando. Esse "vai, vai lendo", na verdade, é a repetição oral das vogais.

Dias depois, volto ao assunto Maria de Nazaré, que não está vindo à escola. A professora me informa que ela não veio a semana toda. "Está com os problemas dela lá". "Sabe que ensinei até uma melodia para ver ser ela aprende a letra "e"? É assim: ra-ra-ra, re-re-re, ri-ri-ri, ro-ro-ro, ru, ru, ru.... Acho que agora ela aprendeu" - diz a professora sorrindo. Iracy ouve e sorri, ironicamente. Minutos depois, enquanto servíamos o lanche:

"- Ontem ela veio aqui...coitadinha da D. Maria de Nazaré. Você não sabe o que aconteceu com ela...". E faz uma expressão de piedade e pena. "...Pois o ex-marido dela voltou e não bateu muito na coitadinha? Olhe, deixou a pobrezinha toda machucada... Você já viu uma coisas dessas? Só porque ela arranjou um namorado mais novo que ele. Agora veja, a pobrezinha é sozinha, vive sozinha, é sozinha de tudo, não tem ninguém, vive naquela 
casa, só ela e a casa... E o marido que vivia enganando ela, passava ela para trás, e que foi embora, imagine, agora voltou e bateu muito na coitadinha. Nem foi pro trabalho e nem veio para a escola. Ontem ela veio aqui me avisar que só vem na segunda feira. Ela não quer vir assim, toda machucada, tem vergonha dos outros alunos ficarem falando dela... Você já viu uma coisa dessas?"

D. Maria de Nazaré vive numa encruzilhada. Por sua história atravessam-se outras histórias que lhe tomam, de imediato, a possibilidade de ser sujeito de si mesma. Vive mediada por relações de dominação e de poder, em muitas dimensões, mas que, por entre os interstícios dessa dominação, busca ir tecendo com os fios frágeis de seus desejos, vontades e necessidades, uma outra história para si mesma. "- Eu moro sozinha, sozinha. Tenho dois filhos, o menino está para Mato Grosso e a menina já casou e mora noutro bairro" murmurou-me ela, certo dia, durante uma fugidia conversa no lanche.

$\mathrm{O}$ olhar em direção à escola, é prenhe de simbolismos. Sua presença, como dominada, expropriada, humilhada, espancada, sintetiza, nela, o papel simbólico que, para ela, a escola representa: a esperança $^{3}$ e o domínio de si mesma, pela apropriação dos conhecimentos que esta veicula. Vigotski tem razão, a necessidade mobiliza o sujeito a superar-se, a desenvolver-se, através das trocas intersubjetivas.

Busca na escola o encontro com o outro e com o conhecimento para constituir-se em sua humanidade, porque "é no movimento, mediado pelo "outro" que aprendemos e apreendemos o vivido, que

3 - "Em certos depoimentos de analfabetos sente-se um poder quase místico emprestado à escola, poder de transformar as relações de dominação e de vencer as diferenças de fortuna" (MELLO e GOMES, 1992). 
nos elaboramos, que reafirmamos e transformamos o que somos, que nos desenvolvemos e singularizamos" (FONTANA, 2000c, p. 174).

Mas, a aprendizagem apresenta-se-lhe, por conseqüência, como um mundo de paciência, submissão, sacrifício e obediência. Ela não reclama, não grita, não se opõe verbalmente à professora. A enunciação é dada sob determinadas condições de produção, mediadas por relações hierárquicas de poder. Bakhtin (1997) chama a atenção para a "influência poderosa que exerce a organização hierarquizada das relações sociais sobre as formas de enunciação" (p. 43).

A longa cabeleira, castanho-claro, encaracolada deita-se por sobre suas costas. Tem bom gosto no vestir: suas roupas são bem feitas e de bom pano. Dão-lhe um ar de certa elegância e seriedade, senhoril. A olhá-la de longe, não lembra a doméstica esfalfada de trabalho e nem a tímida aluna de memória fraca, incapaz para as prendas escolares.

A figura quase imóvel, em sua carteira, a desfiar seu rosário de penitência, revela-se emblemática, simbólica de outras miríades de criaturas, igualmente Marias na sorte e na sina. Sua presença remetenos à viva lembrança dessas, todas unidas a ela pela linha imaginária, mas real e verdadeira, que lhes vinca o destino comum: o de serem mulheres, pobres e analfabetas, subordinadas e dominadas, obedientes - criaturas destinadas a calar, silenciar, segurar a tensão emocional, a controlar a explosão. Maria de Nazaré, igual a outras mulheres presentes na sala, na sorte e na sina, na alfabetização retardada, num bairro mal afamado, pobre e miserável.

D. Maria de Nazaré, na riqueza de sua expressividade emocional: em sua angústia e medo, esperança e coragem ${ }^{4}$ de aproximar-se da escola em busca de seus possíveis, em seu corpo mortificado, dor de cabeça e nervosismo, em sua obediente aceitação à fatigante tarefa mnemônica, em sua frágil e fugaz alegria por aprender umas 
"coisinhas" - nesse previsível e desencorajador percurso no qual as suas forças mobilizadoras esvaem-se a cada encontro com as letras, demonstra-nos formas sociais, históricas, culturais e específicas de viver e manifestar suas emoções, conforme seu lugar social, sua pertença de classe, etc..

Em sua singularidade realiza-se a síntese de múltiplas interações sociais, de forma que "a organização de suas emoções está claramente referida a esse seu modo de imersão cultural" (OLIVEIRA e REGO, 2003, p. 29). Assim, a sua vida emocional e afetiva é constituída histórica e culturalmente e dá-se a ver no contexto das relações intersubjetivas, no qual a condição hierárquica dos interlocutores não pode ser desconsiderada, pois, conforme Bakhtin (1997) observa, o lugar social do sujeito determina a modulação do acento enunciativo.

Com base no pensamento de Vigotski, pode-se dizer que Maria de Nazaré constitui sua vida psíquica - da qual fazem parte o afetivo e o emocional - no contexto das relações sociais, no entrelaçamento dos diversos e diferentes componentes de sua biografia: como mulher, mãe, ex-esposa, analfabeta, empregada doméstica, que exerce uma função sem quase nenhum reconhecimento social, moradora de um distante e discriminado bairro, encravado na periferia, membro de uma classe subalternizada, desprovida de bens econômicos, pois, como observa Sève, a base de transmissão [da vida humana] "não está inscrita num programa psíquico", mas no social, portanto, descentrado, "inclusive nas realidades não psíquicas, sendo "graças a sua apropriação parcial, psiquicamente mediada por outrem, que ela se individualiza humanamente por intermédio de uma biografia inesgotavelmente singular" (1989, p. 155).

4 - Kurt Goldstein, médico e fisiólogo especialista em lesões cerebrais, viu na coragem, como "sentimento do possível", o meio de sair da angústia, que é o sentimento da inadequação do organismo à sua função vital, à sua relação com o mundo"(ABBAGNANO, 1998). 
Assim, segundo a perspectiva teórica histórico-cultural, tem ela sua singularidade, que é a sua história pessoal, construída nas relações sociais, mas composta dos sentidos e significados que atribui às suas vivências, experiências, isto é, ao que vive, como vive e como sente, de forma que seus processos afetivos são construídos "ao longo de sua história pessoal, inserida numa condição histórico-cultural específica" (OLIVEIRA e REGO, 2003, p. 32). Diante disso, pode-se supor que as formas de viver e manifestar sua vida emocional e afetiva estão profundamente relacionadas com esses aspectos que as constituem. Suas emoções, assim, indiciam os modos como a mesma relaciona-se nos diferentes contextos sociais e culturais.

Na busca de seu desenvolvimento, que é a superação de sua condição de analfabeta, e portanto, da emergência de possibilidades de assumir um outro lugar no contexto das relações sociais - como alfabetizada, Maria centra seus investimentos afetivos e cognitivos sua esperança, sua coragem, seu esforço - naqueles sentidos e significados que representam o caminho socialmente valorizado para a aquisição do saber, mas, não tem sucesso em seu empreendimento, que resulta infrutífero.

Assim, contrariamente, as demandas psíquicas que a mobilizam em direção à aprendizagem, diante das condições adversas de sua inserção na relação com o conhecimento, vão, continuamente, desgastando-se, enfraquecendo, certamente porque aqueles sentidos que a movem não se realizam no plano concreto de sua experiência: a relação de aprendizagem apresenta-se sem sentido e sem significado, porque incapaz de produzir mudanças em sua condição de analfabeta. Descobrindo-se não-aprendendo, os sentidos perdem a sua substância mobilizadora, cedendo lugar à outros sentidos que a levam a desmobilização, ao cansaço, a dor, à tristeza e, por fim, à desistência.

Por que não reagiu? Por que não lutou por um ensino que realizasse 
os sentidos e os significados por ela esperados: aprender a ler e escrever? A sua reação ou não, a sua passividade - se é que posso usar tais termos - , não podem ser vistas fora de sua história, que é singular e única. Estaria presente, em sua atitude, que parece-me mais de aceitação, uma questão de gênero? Essa não é uma questão irrelevante.

Certamente, sua atitude, que, pelos fragmentos narrados, indiciam uma certa submissão à prática pedagógica, pode ser vista como parte da constituição histórico-cultural de nossa personagem, enquanto mulher, marcada em sua biografia por todos aqueles predicativos acima arrolados, inserida numa sociedade cuja questão de gênero encontra-se, em sua complexidade, entrelaçada aos pertencimentos de classe, poder econômico, educação, cultura e grupo social.

Assim, em sua condição de mulher, inserida nesse emaranhado de investimentos de sua pertença de classe, vivendo relações de ensino e aprendizagem, que, por sua vez, constituem relações hierarquizadas de poder, seria presumível - a meu ver - esperar que D. Maria de Nazaré vivesse e manifestasse a sua vida afetiva da forma como manifestou e viveu, enunciando emoções de obediência materializadas no esforço infrutífero, solidão, dor, sofrimento, angústia e desesperança, por exemplo, pois, como observa Oliveira e Rego, "interagindo com a pertinência de classe aparece a condição de gênero estruturando [as] emoções" (2003, p.29). Deste modo, suas manifestações afetivas expressariam, em sua condição de mulher singular, uma certa configuração afetivo-emocional que é social, histórica e culturalmente construída ao longo de sua inserção na vida social e que, no contexto da vida concreta, nas relações sociais, é esperada e valorizada.

Poderia, ainda, a título de suposição, argumentar que D. Maria, pelo contrário, não aceitou, não foi passiva, mas reagiu à insatisfação e ao aborrecimento que vivia e o fez de forma radical, 
realizando aquilo que já havia antecipado-me em um de nossos raros contatos, em sua miúda e recolhida voz: "Se eu não aprender, acho que não venho mais". Cumpriu a sua profecia. Os sentidos que a mobilizaram foram reconfigurados em outros que a levaram à desistência e, portanto, ao fechamento de uma das possibilidades de realização daqueles sentidos que se lhe apresentavam mais caros, indispensáveis, urgentes e necessários à sua vida. As emoções que a mobilizaram à escola, foram re-significadas na relação estéril e improdutiva que ela teve com o conhecimento, produzindo, assim, outros desdobramentos, ou, mais especificamente, aquilo que Janet denominou de emoção-choque ${ }^{5}$, que define a reação de fracasso. [Ele também chama de emoção-sentimento, à emoção responsável pelo controle adequado da conduta (ABBAGNANO, 1998)].

Certamente que essas considerações não esgotam outras possibilidades de análise desses fragmentos que compõem apenas uma incompleta faceta da biografia de D. Maria de Nazaré.

5 - E que outras teorias, segundo Abbagnano chamam de conduta emotiva, oposta à emoção-controle. Para estas teorias, a emoção também é parte integrante da conduta não emotiva e constitui uma resposta adequada e normal à situação, e que pode ser definida como "racional". Assim, por ex., as emoções da coragem, do esforço, da fadiga, da esperança ou do temor, da satisfação ou da insatisfação, etc., condicionam e controlam as formas de conduta mais eficazes, livres e criativas (ABBAGNANO, 1998). 


\section{Referências}

ABBAGNANO, N. Dicionário de Filosofia. São Paulo: M. Fontes, 1998.

ALMEIDA, D. D. M. de. Por uma pedagogia apaixonada. Educação \& Linguagem - Revista da UMESP/SP, São Paulo, Ano 2, N. 2, 1999.

. Por uma pedagogia apaixonada. Educação \& Linguagem - Revista da UMESP/SP, Ano 4, N. 4, 2001.

BAKHTIN, M. M. Hacia una filosofía del acto ético; de los boradores y otros escritos. Rubí (Barcelona): Anthropos, San Juan: Universidad de Puerto Rico, 1997.

. Marxismo e filosofia da linguagem. São Paulo: Hucitec, 1997.

. Estética da criação verbal. São Paulo: Martins Fontes, 2000.

. Questões de literatura e de estética: a teoria do romance. São Paulo: Annablume, HUCITEC, 2002.

BARBOSA, J. J. Alfabetização e Leitura. São Paulo: Cortez, 1994.

BOSI, E. Memória e Sociedade: lembranças de velhos. São Paulo: T. A. Queiroz, 1983.

BRAGGIO, S. L. B. Leitura e Alfabetização: da concepção mecanicista à sociopsicolingüística. Porto Alegre: Artes Médicas, 1992. CHARLOT, B. Da Relação com o Saber: elementos para uma teoria. Porto Alegre: Artes Médicas, 2000.

CHAUI, M. O que é Ideologia. São Paulo: Brasiliense, 1981.

. Os trabalhos da memória. In: BOSI, E. Memória e Sociedade: lembranças de velhos. São Paulo: T. A. Queiroz, 1983.

FONTANA, R. A. C. Nas relações de ensino, o aprendizado da escuta. In: ALMEIDA, M. J. P. M de; SILVA, H. C. (org.). Textos, Palestras e Sessões Temáticas. III Encontro Linguagens, leituras e ensino da ciência. Campinas, FE/UNICAMP, $2000^{\mathrm{a}}$.

. Trabalho e subjetividade. Nos rituais da iniciação, a constituição do ser professora. CEDES, ano XX, n. 50, abril, 2000b.

. Como nos Tornamos Professoras? Belo Horizonte: Autêntica, 
2000c.

. Sobre a aula: uma leitura pelo avesso. In: Presença Pedagógica. v. 7, n. 39, abril/maio, 2001.

. A professora em silêncio: fragmentos de um processo singular de constituição. In: SHIGUNOV NETO, A. et al. Desatando os nós da Formação Docente. Porto Alegre: Mediação, 2002.

GINZBURG, C. Mitos, Emblemas, Sinais. São Paulo: Cia das Letras, 1989.

GÓES, M. C. R. Relações entre desenvolvimento humano, deficiência e educação: contribuições da abordagem histórico-cultural. In: OLIVEIRA, M. K.; SOUZA, D. T. R.; REGO, T. C. (Orgs). Psicologia, Educação e as Temáticas da Vida Contemporânea. São Paulo: Moderna, 2002.

. A natureza social do desenvolvimento psicológico. CEDES, Campinas, n. 24, 1991.

. As relações intersubjetivas na construção de conhecimentos. In:

SMOLKA, A. L. B. (orgs.) A Significação nos Espaços Educacionais; interação social e subjetivação. Campinas: Papirus, 1997.

- A abordagem microgenética na matriz histórico-cultural: uma perspectiva para o estudo da constituição da subjetividade. CEDES, ano XX, N. 50, 2000.

GÓES, M. C. R. de; LOPES, P. A linguagem do brincar: repercussões do "faz-de-conta" para o processo de letramento. In: LODI, A. R. B. et al (orgs.). Leitura e Escrita no Contexto da Diversidade. Porto Alegre: Mediação, 2004.

HEILBRUN, C. G. Writing a Woman's Life. New York : Ballantine Books, 1988.

MELLO, S. L. de; GOMES, J. V. O que pode ler o iletrado? Revista Travessia, jan/abr, 1992.

MELLO, T. Poemas Preferidos pelo Autor e seus Leitores. Rio de Janeiro: Bertrand Brasil, 2001.

MELO, O. C. Alfabetização e Trabalhadores: o contraponto do 
discurso oficial. Campinas: Ed. da UNICAMP; Goiânia/GO: Editora da UFG, 1997.

MORTATTI, M. do R. L. Os Sentidos da Alfabetização. São Paulo: UNESP: CONPEDE, 2000.

MOYSÉS, S. A. Alfabetização: estratégia do código ou confronto da história? CEDES, Campinas, n. 22, set/dez, 1985.

OLIVEIRA, I. M. de (Mimeo). A dimensão Afetivo-emocional e Relações de Ensino.

. (2001). O Sujeito que se Emociona; signos e sentidos nas práticas culturais. Tese de Doutorado. UNICAMP, 2001.

OLIVEIRA, M. K. de (Mimeo). Escola e Desenvolvimento Conceitual. Trabalho apresentado no XII ENDIPE. Curitiba, PR, 29/08 a $01 / 09 / 04$.

- Analfabetos na sociedade letrada: diferenças culturais e modos de pensamento. Revista TRAVESSIA, jan. abr, 1992.

. O problema da afetividade em Vygotsky. In: LA TAILLE, Y. de. Piaget, Vygotsky, Wallon: teorias psicogenéticas em discussão. São Paulo: Summus, 1992.

. Letramento, cultura e modalidades de pensamento. In: KLEIMAN, A. B. (Org.) Os Significados do Letramento. Campinas: Mercado de Letras, 1995.

- Sobre diferenças individuais e diferenças culturais: o lugar da abordagem histórico-cultural. In: AQUINO, J. G. (org.) Erro e Fracasso na Escola: alternativas teóricas e práticas. São Paulo: Summus, 1997.

. Vygotsky: aprendizado e desenvolvimento; um processo sóciohistórico. São Paulo: Scipione, 1997.

. O pensamento de Vygotsky como fonte de reflexão sobre educação. CEDES, Campinas, n. 35, jul., $2^{2}$ edição, 2000.

OLIVEIRA, M. K de; REGO, T. C. Vygotsky e as complexas relações entre cognição e afeto. In: ARANTES, V. A.; AQUINO, J. G. (Orgs). Afetividade na Escola: alternativas teóricas e práticas. São Paulo: Summus, 2003.

PADILHA, A. M. L. Processo de simbolização e inserção cultural do 
deficiente mental (um estudo de caso). In: Comunicações - Revista do Programa de Pós-Graduação em Educação da Universidade Metodista de Piracicaba. Ano 9, n. 2, nov., 2002.

. Práticas Pedagógicas na Educação Especial. Campinas: Autores Associados, 2001.

Possibilidades de Histórias ao Contrário ou como Desencaminhar o Aluno da Classe Especial. São Paulo: Plexus, 1997. PINO, A. O social e o cultural na obra de Lev S. Vigotski. CEDES, Campinas, n. 71, outubro/ 2000.

. O social e o cultural na obra de Vigotski. In: Educação \& Sociedade, ano XX1, n. 71, jul, 2000.

. (Mimeo). Afetividade e Vida de Relação. Campinas: FE/UNICAMP.

ROCHA, M. S. P. M. L. da O Real e o imaginário no faz-de-conta: questões sobre o brincar no contexto da pré-escola. In: GÓES, M. C. R. de; SMOLKA, A. L. B. (Orgs). A Significação nos Espaços Educacionais: interação e subjetividade. Campinas: Papirus, 1997. SÈVE, L. A personalidade em gestão. In: SILVEIRA, P.; DORAY, B (Orgs). Elementos para uma teoria marxista da subjetividade. São Paulo: Vértice, Ed. Revista dos Tribunais, 1989.

SILVA, L. H. A. Modos de Mediação de um Formador de Área Científica específica na Constituição Docente de Futuros Professores de Ciências/biologia. Piracicaba: FE/UNIMEP (Tese de Doutorado), 2004.

SILVA, Z. B. Negociações de Destino: a escola pública como espaço de constituição de jovens e professores. Campinas: FE/UNICAMP, dissertação de mestrado, 2003.

SMOLKA, A. L. B. Esboço de uma perspectiva teórico-metodológica no estudo de processos de construção de conhecimento. In: GÓES, M. C. R.

. (orgs.) A significação nos Espaços Educacionais: interação social e subjetivação. Campinas: Papirus, 1997.

. A prática discursiva na sala de aula: uma perspectiva teórica e um 
esboço de análise. CEDES, Campinas, v. 24, jul., 3 edição, 2000.

. Construção de conhecimento e produção de sentidos nas relações de ensino. ALMEIDA, M. J. P. M de; SILVA, H. C. (org.). Textos, Palestras e Sessões Temáticas. III Encontro Linguagens, leituras e ensino da ciência. Campinas: FE/UNICAMP, 2000.

. O (im)próprio e o (im)pertinente na apropriação das práticas sociais. CEDES, Campinas, n. 50, abril, 2000.

. A Criança na Fase Inicial da Escrita: a alfabetização como processo discursivo. Campinas: Cortez, Ed. UNICAMP, 2001.

SMOLKA, A. L. B.; GÓES, M. C. R. de (Orgs.). A Linguagem e o Outro no Espaço Escolar: Vygotsky e a construção do conhecimento. Campinas: Papirus, 1993.

SNYDERS, G. Alunos Felizes: reflexões sobre a alegria na escola a partir de textos literários. São Paulo: Paz e Terra, 2001.

TASSONI, E. C. M. Afetividade e Produção Escrita: a mediação do professor em sala de aula. Campinas, FE/UNICAMP (Dissertação de Mestrado), 2000.

VAN DER VEER, R; VALSINER, J. Vygotsky; uma síntese. São Paulo: Loyola, 2001.

VIGOTSKI, L. S. As emoções e seu desenvolvimento na infância. In:

O Desenvolvimento Psicológico na Infância. São Paulo: Martins Fontes, 1999.

. Pensamento e Linguagem. São Paulo: M. Fontes, 2000a.

. A Formação Social da Mente; o desenvolvimento dos processos psicológicos superiores. São Paulo: M. Fontes, 2000b.

. Manuscrito de 1929. CEDES, Campinas, n. 71, out/2000c.

. A Construção do Pensamento e da Linguagem. São Paulo: M. Fontes, 2001.

. A Educação do comportamento emocional. In: _. Psicologia Pedagógica. Edição comentada. Porto Alegre: Artes Médicas, 2003. VYGOTSKI, L. S. Obras Escogidas. Madrid: Visor. v. II, 1993.

. Fundamentos de Defectologia. Obras Escogidas. Madrid: Visor. v. $\mathrm{V}, 1997$. 